\title{
Differentiering og bevidstgørelse i det fremmedsproglige e-læringsrum
}

\author{
Lone Ambjørn \\ Lektor \\ Institut for Sprog og Erhvervskommunikation \\ Aarhus School of Business (ASB) \\ lam@asb.dk \\ http://www.asb.dk/staff/langcom/lam.aspx
}

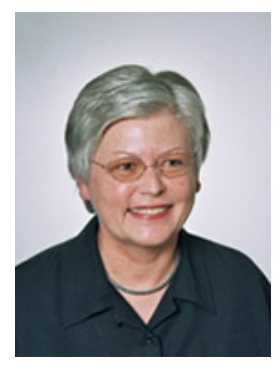

Lone Ambjørn underviser på BA-studiet i spansk på ASB og har tidligere undervist på masterstudiet i 'It, sprog og lecring” på it-vest (2000 - 2004.) Fra 2006 underviser hun også på adjunktuddannelsen på ASB. Lone Ambjørns forskningsområder er sproglige leeringsprocesser, sproglig lecring og IT, netvcerksstøttet sproglig leering og talesprogsdiskurs. Hun driver desuden en konsulent- og foredragsvirksomhed inden for de gymnasiale uddannelser.

\section{Indledning}

I Ambjørn (2003) er min udgangsreplik, at undervisningsdifferentiering er computermediets raison d'être inden for sproglig læring. Samme skal her være min indgangsreplik.

I det heterogene læringsrum tilpasses undervisningens niveau, indhold og form ofte en standardiseret forløbsmodel, der formodes at være i overensstemmelse med den "typiske" studerendes færdigheder, behov og interesser. Sådanne one-size-fits-all modeller møder ikke den enkelte studerende dér, hvor h/n rent faktisk befinder sig i sin intersproglige udvikling, men forudsætter, at de "atypiske" studerende tilpasser sig normen (Tomlinson 2000).

E-læring udløser selvsagt ikke per se undervisningsdifferentiering. Det påhviler derfor underviserne at tilrettelægge sproglige læringsforløb, der er baseret på en kritisk selektering og sammensætning af en bred vifte af forskelligt elektronisk materiale på forskellige niveauer og med forskellige læringsmæssige delmål.

At adgangskriteriet til et sprogstudium på en højere læreanstalt er et fastlagt antal år inden for de gymnasiale uddannelser, har ikke den store betydning i praksis. Min undervisningsvirkelighed er anderledes nuanceret: Foruden de studerende, der kommer direkte fra de gymnasiale uddannelser på forskellige niveauer, har nogle studerende efter den gymnasiale uddannelse været i et spansktalende land i en kortere eller længere periode, medens andre ikke har beskæftiget sig med spansk i en kortere eller længere årrække. Dette betyder, at der på et hold er repræsenteret vidt forskellige sproglige niveauer, hvilket gør differentiering til en uomtvistelig nødvendighed.

Foruden undervisningsdifferentiering er indtænkning af bevidstgørelse i et forløb et lige så nødvendigt led i at optimere e-læringens potentiale. Igennem tiderne har det ikke fra sprogundervisers side skortet på gode råd til den studerende om at få læst, lyttet, skrevet og talt så meget som muligt på fremmedsproget. Hvordan disse råd mere konkret skulle efterleves i praksis, har historien generelt meldt lidt mindre om.

Nu, hvor vi har elektroniske værktøjer og internet til vores disposition, behøver disse råd ikke længere at være en halvtom floskel. Men de kan fortsat være det, hvis de studerende ikke bevidstgøres om, hvad de helt konkret bør foretage sig for at udvikle deres sproglige færdigheder, og hvad den læringsteoretiske begrundelse for rådene er. Jeg er hermed inde på betydningen af, 
at sprogindlæreren besidder en primært metakognitiv bevidsthed omkring generelle og færdighedsspecifikke aspekter af sproglig læring, omkring læringsmæssige formål med givne aktiviteter samt metoder og indfaldsvinkler til at nå et givet mål.

\section{Samarbejde og medansvar}

I det følgende belyse skal jeg belyse, hvordan jeg indtænker differentiering og bevidstgørelse i egen undervisning. ${ }^{1}$

Til en begyndelse bevidstgør jeg de studerende om de to koncepter, der ligger til grund for min undervisningsform: samarbejde og medansvar. Samarbejdet imellem underviser og studerende samt imellem de studerende indbyrdes om udvikling af deres sproglige færdigheder hægter jeg teoretisk op på Selinkers (1972) intersprogskoncept ${ }^{2}$ og får på den måde samtidigt indledt mine studerendes 'læring om sproglig læring'.

Imellem intersprog og medansvar er der en klar relation. Trods mulig støtte fra andre fordres der i sagens natur en aktiv og medansvarlig adfærd fra sprogindlærerens side, hvis læringsprocessen skal lykkes. Og endnu tydeligere bliver relationen imellem intersprog og medansvar, når differentiering, og dermed hensynet til den enkeltes intersproglige udvikling, medtænkes.

Uden den fornødne indsigt i diverse forhold omkring sproglige læringsprocesser kan imidlertid hverken et ægte samarbejde eller et ægte medansvar realiseres. Jeg bevidstgør derfor igennem studiets første og andet semester de studerende om flg. generelle aspekter inden for sproglig læringsteori:

- intersproget, dets omstrukturering, dets nonlineære og nonkumulative udvikling,

- arbejdshukommelse vs. langtidshukommelse,

- kognitiv bearbejdningskapacitet,

- $\quad$ kontrollerede og automatiske processer ${ }^{3}$,

- $\quad$ hypotesen om den kritiske periode. ${ }^{4}$

Disse emner er også valgt, fordi jeg ofte har brug for at referere til dem i den procesorienterede læringsvejledning, jeg løbende tilbyder mine studerende. De udgør således det teoretiske grundlag både for den enkelte studerendes individuelle sproglige udvikling og for vores samarbejde om læringsprocessen.

De studerende introduceres ikke alene for generelle, men også for udvalgte færdighedsspecifikke aspekter af sproglig læring med direkte relation til faget. Disse vil jeg komme nærmere ind på i de følgende afsnit.

\section{E-læring og den leksikalske kompetence}

Når man taler om oparbejdelse af et ordforråd på fremmedsproget, skelner man mellem den direkte og den indirekte indfaldsvinkel (Nation 1982,1990). Mange går ud fra, at ordforrådet i tilstrækkeligt omfang automatisk tilegnes indirekte igennem forskellige former for kontakt med fremmedsproget. Men selv om det er vigtigt at læse, lytte, skrive og tale så meget som muligt og i så varierede kontekster som muligt, knytter der sig visse problemer til den indirekte indfaldsvinkel.

Især ekstensiv læsning og dennes relation til udviklingen af den leksikalske kompetence er genstand for en del opmærksomhed inden for forskningen. Forskellige undersøgelser (bl.a. Prince 1996; Coady 1997b; Paribakht/Wensche 1997) viser, at udviklingen af den leksikalske kompetence gennem ekstensiv læsning uden bevidst fokus på gloser

- ikke er særlig effektiv, når det gælder ordforrådets kvantitet,

- ikke er særlig effektiv, når det gælder hastighed i oparbejdelsen af ordforrådet,

- ikke sikrer, at sprogindlærerens receptive ordforråd kan anvendes i sproglig produktion, 
- ikke er velegnet, når det gælder oparbejdelse af et mere specialiseret ordforråd, som fx teknisk, juridisk eller økonomisk sprogbrug.

Dertil kommer, at man skal være i besiddelse af et ret stort ordforråd for overhovedet at kunne tilegne sig nye gloser via ekstensiv læsning. Man regner med, at en indfødt sprogbruger gennemsnitligt behersker 20.000 ordfamilier $^{5}$ på sit modersmål (Nation/Waring 1997). For sprogindlæreres vedkommende viser undersøgelser (Hirsh/Nation 1992; Nation/Newton 1997; Coady 1997) at de, for at kunne udtrykke sig og forstå fremmedsproget på et helt elementært niveau, skal have kendskab til ca. 2-3000 ordfamilier. Kendskab til ca. 98 \% af ordforrådet i en autentisk tekst, svarende til et ordforråd på ca. 5000 ordfamilier, er imidlertid en forudsætning for, at kvaliteten af læsningen er optimal og der reelt kan finde en glosetilegnelse sted via ekstensiv læsning af autentiske tekster. Årsagen hertil er bl.a. sprogindlærernes reducerede mulighed for hensigtsmæssig ordbearbejdning (evne til at drage slutninger), når ordforrådet ikke har det fornødne omfang (Huckin/Coady 1999).

Spørgsmålet er så, hvordan sprogindlærere kan tilegne sig nok gloser igennem ekstensiv læsning, hvis de ikke har et tilstrækkeligt ordforråd til at kunne få det fornødne udbytte af læsningen. Denne problemstilling, der i litteraturen på området benævnes "the beginner's paradox", synes helt klart at indikere, at man må sætte mere målrettet ind, når det gælder oparbejdelse af den leksikalske kompetence, ikke mindst på de lave(re) undervisningsniveauer.

På spanskstudiet anvendes det elektroniske gloseværktøj, gtPlus. ${ }^{6}$ Programmet, som jeg har været pædagogisk konsulent på, placerer sig inden for den direkte metode til gloseindlæring og fungerer dermed som et supplerende værktøj til den glosetilegnelse, der finder sted igennem den indirekte metode.

Værktøjet udmærker sig ved at være udviklet på basis af indlæringspsykologiske forskningsresultaters påpegning af værdien af gentagen træning fordelt over tid. Allerede siden Ebbinghaus (1885) har man vidst, at gentagen træning med passende tidsintervaller er en mere effektiv fremgangsmåde end intensiv træning inden for et kort tidsrum. Det vil sige, at man husker bedre og bedre for hver gentagelse, i særdeleshed når intervallerne imellem gentagelserne gradvist øges. Specifikt inden for gloseindlæring har dette indlæringspsykologiske princip fundet sin anvendelse hos bl.a. Leitner (1972), Landauer/Bjork (1978), Mondria/Mondria-De Vries (1994), som alle sammenkæder den såkaldte intervalmetode med direkte glosetræning via kartotekskasser og påviser denne metodes effektivitet.

I gtPlus tilgodeses differentieringstanken ved, at der ikke, som i de fleste andre elektroniske programmer til ordforrådsindlæring, er forhåndsindlagt et givet antal niveaubestemte gloser. ${ }^{7}$

Grundtanken med programmet er, at brugerne, med medansvar for udviklingen af egen leksikalsk kompetence, selvstændigt skal opbygge deres eget glosekartotek, der således tilpasses den enkeltes leksikalske behov og interesser (Ambjørn 2001b).

Når det drejer sig om færdighedsspecifikke sider af sproglig læring med særligt henblik på den leksikalske kompetence, bevidstgør jeg de studerende om flg. aspekter, som jeg betragter som en forudsætning for det optimale udbytte af det direkte arbejde med ordforrådet:

- ordforrådets størrelse, herunder "the beginner's paradox",

- $\quad$ indirekte vs. direkte tilgang til udviklingen af den leksikalske kompetence,

- intervalmetoden,

- høj-, mellem- og lavfrekvente gloser. 


\section{E-læring og tekstlæsning}

Til udvikling af mundtligheden på spanskstudiets 1 . - 3. semester $^{8}$, arbejdes der ud fra tolv overordnede emneområder:

$\begin{array}{llll}\text { Blok 1 } & \text { Personlig identifikation } & \text { Blok 7 } & \text { Velfcerd for mennesker og dyr } \\ \text { Blok 2 } & \text { Fritid og interesser } & \text { Blok 8 } & \text { Uddannelse og studier } \\ \text { Blok 3 } & \text { Daglig rutine } & \text { Blok 9 } & \text { Arbejdsmarkedet } \\ \text { Blok 4 } & \text { Ernæring og sundhed } & \text { Blok 10 } & \text { De unge } \\ \text { Blok 5 } & \text { Boligen og dens omgivelser } & \text { Blok 11 } & \text { Parforhold og kønsroller } \\ \text { Blok 6 } & \text { Menneskets ydre og indre } & \text { Blok 12 } & \text { Danmark og danskerne }\end{array}$

Hver af disse emneblokke er underopdelt i relaterede emner, fx blok 10 (De unge) og deres forhold til: uddannelse, politik, alkohol og stoffer, miljøet, religion, traditioner, familien som institution, det teknologiske samfund.

På fagets hjemmeside ${ }^{9}$ linker jeg til spanske artikler og websteder, der på forskellig vis rummer informationer inden for udvalgte emner. Differentieringen kommer her til udtryk i den enkelte studerendes mulighed for at vælge læsestof ud fra kriterier som mængde, længde og kompleksitet. Disse tekster læses overvejende intensivt med fokus på emnerelateret ordforråd. ${ }^{10}$

Som forberedelse til samtaletræningen, som de studerende udfører i mindre grupper, skal de brainstorme emnerne med henblik på en perspektivering. Der kan her være tale om uddybelse af emner, egne meninger på området, personlige erfaringer og løsningsforslag til givne problemstillinger. Hermed påkobles differentieringen endvidere aspekter som interesse og konkrete behov. Dette medfører i praksis, at de enkelte samtaleopgaver, der ligger til grund for træningen, gribes ret så forskelligt an fra gruppe til gruppe. Og dette indebærer på sin side, at grupperne selv skal supplere teksterne/webstederne fra fagets hjemmeside med andre, som de finder frem til via søgning i Google. Dette læsestof behandles overvejende ekstensivt, da indholdet primært bruges som inspirationskilde til samtalens emner. Dog kan de studerende vælge at læse (dele af) deres selvvalgte materialer mere intensivt, hvis de indeholder gloser, som de får brug for i løbet af samtalen.

Ifølge Seelye/Day (1971) er løbende læsning af avisoverskrifter + manchetter bl.a. et godt udgangspunkt for at træne de studerende i at inkorporere dagens hovednyheder i deres samtaler på fremmedsproget. Dette har både en god kontaktskabende funktion, og det er på samme tid en måde, hvorpå de studerende kan vise, at de er orienterede om, hvad der foregår omkring dem. Dette er vigtigt led i at være en god samtalepartner. Derfor opfordrer jeg de studerende til, sideløbende med den øvrige læsning, jævnligt at skimme spanske online aviser og læse overskrifter med tilhørende manchet.

En gang om ugen inden for 1. og 2. semester bliver en af de samarbejdsgrupper, der er etableret på holdene, bedt om at udfærdige tre resumeer af læste overskrifter + manchetter samt anføre emnerelevante spanske nøgleord fra hver. Det hele lægges i en dertil indrettet tråd i et debatforum i vores e-læringsplatform, CampusNet. Endvidere linker den ansvarlige gruppe i samme indlæg til de pågældende artikler, så de andre studerende på holdet, sammen med underviseren, i efterfølgende indlæg kan deltage i en computermedieret diskussion på dansk om resumeernes beskaffenhed.

Emnemæssigt har de studerende frit valg, men af hensyn til deres læsefærdighed samt leksikalske kompetence er det vigtigt, at de konsekvent vælger forskellige emner og ikke kun læser fx sports- eller modesider. 
I den første halvdel af undervisningsforløbet udarbejdes resumeerne på dansk, da de dels skal bruges til at bevidstgøre de studerende om denne teknik ${ }^{11}$, dels tjekke deres forståelse af hvad de har læst. ${ }^{12}$ I anden halvdel af forløbet resumeres der på spansk med et skift i træningsfokus fra reception til produktion.

Blandt forskere inden for læseforståelse er der bred enighed om, at sprogindlærerens baggrundsviden spiller en vigtig rolle i betydningsafklaringen (Grabe 2004). Denne erkendelse bruger jeg i differentieringsøjemed på den måde, at jeg som igangsættende foranstaltning af læsning af autentisk stof på spansk anbefaler enten almengyldige eller internationale informationer, som de studerende i forvejen er bekendte med fra dansk presse. Artikler med et kendt indhold er generelt lettere at afkode end dem, der rummer spanske nationale og lokale nyheder. De spanske nationale nyheder kan igen deles op i sværere og lettere emner i henhold til den enkelte studerendes forhåndsviden. De helt lokale nyheder er som hovedregel de sværeste at afkode, fordi de forudsætter en baggrundsviden, som den studerende sjældent besidder.

I forbindelse med tekstlæsning og det optimale udbytte heraf, bevidstgøres de studerende om

- formålet med de forskellige former for læsning i faget,

- læsestrategien skimming, hvor man lader øjnene løbe ned over teksten for at få et overblik over dens indhold og få fat i det væsentligste i budskabet,

- ekstensiv læsning med sigte på den globale forståelse af teksten uden nævneværdig fokus på det sproglige udtryk,

- intensiv læsning med sigte på den detaljerede forståelse af teksten med fokus på såvel den syntaktiske som den semantiske del af det sproglige udtryk,

- betydningen af baggrundsviden i læseforståelsen,

- betydningen af evnen til at foretage kvalificerede gæt i afkodningsprocessen (Haastrup 1989).

\section{E-læring og det fremmedsprogede univers}

Et generelt problem på en højere læreanstalt er mange sprogstuderendes skæve opfattelse af, at antallet af udbudte timer og forberedelsen hertil er ligefremt proportionelt med den indsats, der er påkrævet for at sikre den optimale intersproglige udvikling inden for diverse færdigheder. Dette hænger på sin side sammen med manglende forståelse af forholdet imellem rollerne som sprogindlærer og studerende.

Som studerende får de i undervisningen input og støtte inden for de områder af sproget, som man inden for det pågældende studium har valgt at fokusere på. Imidlertid er målet for en sprogindlærer ideelt set at nå så højt op ad intersprogsskalaen som muligt, og hertil fordres der selvsagt en langt større indsats, end undervisningens reelle omfang lægger op til. Derfor kan det i denne sammenhæng anbefales at bevidstgøre de studerende om, at de udbudte timer i et fag understøtter deres egen intersproglige læringsproces og deres selvstændige arbejde med færdighed $\mathrm{i}$ at tale, skrive, læse og lytte uden for selve undervisningssituationen. I den forbindelse bør de studerende tilstræbe at få skabt 'et fremmedsproget univers' sideløbende med deres egl. studier. Eller sagt på en mere populær måde: De skal et smut til målsprogslandet så ofte som muligt og i intensiveret form i de skemafri perioder.

Som en hjælpeforanstaltning i forbindelse med skabelsen af et spansk univers bevidstgør jeg de studerende om deres roller som hhv. sprogindlærer og sprogstuderende samt om den selvstændige del af e-læringens nærmest uendelige muligheder og store differentieringspotentiale. På fagets hjemmeside linkes til flg.:

- $\quad$ websteder med fokus på forskellige former for sproglige færdigheder, herunder med muligheden af at løse sproglige opgaver online,

- et behørigt udvalg af online aviser, tidsskrifter, blade, 
- $\quad$ spansk radio og fjernsyn med mulighed af at lytte, kombinere lytning og læsning samt kombinere lytning og læsning med videoklip,

- spanske chatrum.

I den tidligere omtalte læringsvejledning, jeg tilbyder mine studerende, diskuterer vi bl.a. den enkelte studerendes muligheder og behov inden for skabelsen af et spansk univers, og vi foretager jævnligt i forløbet justeringer med henblik på at tilgodese den løbende intersprogsudvikling.

\section{Den elektroniske læringsjournal}

Som det er fremgået, betragter jeg metakognitiv bevidsthed som en nødvendig forudsætning for, at de studerende kan tage et ægte medansvar for egen læring. Jeg har i de foregående afsnit været inde på hvilke generelle og færdighedsspecifikke aspekter af sproglig læring, jeg anbefaler at bevidstgøre om med henblik på at give de studerende et teoretisk fundament at bygge medansvaret for egen læring på.

Endnu et vigtigt led i metakognitiv bevidsthed er planlægning og evaluering af egen læringsproces. Udviklingen af den studerendes intersproglige kompetence foregår som nævnt i et samarbejde imellem underviser/vejleder og studerende samt de studerende imellem, og den elektroniske læringsjournal ${ }^{13}$ er et uvurderligt redskab for interaktiviteten i denne samarbejdsproces.

Mine studerende anvender læringsjournalen som et overbliksskabende samlingspunkt for alle de læringsaktiviteter, der foregår, og den er en medvirkende faktor til, at de mere selvstændigt og reflekterende tager hånd om egen læring. Læringsjournalen er en støtte i den løbende strukturering af fagets aktiviteter samt en hjælp til bevidsthed om oparbejdelse af den enkeltes samtalefærdighed.

Det skal understreges, at en læringsjournal skal opfattes som et redskab til procesorienteret vejledning og ikke til produktorienteret evaluering. Den medvirker til over for de studerende at anskueliggøre deres individuelle læringsproces og dermed sætte dem i stand til bedre at forstå, systematisere og kontrollere den.

Læringsjournalen til mit fag tager konkret form af et worddokument indeholdende en skabelon, som udfyldes af de studerende. Med udgangspunkt i de studerendes optegnelser og selvevalueringer kan jeg, med henblik på den optimale vejledning, få det fornødne indblik i, hvordan deres læringsproces forløber og i journalen indskrive råd og kommentarer. Vi bruger også læringsjournalerne som udgangspunkt for løbende vejledningsseancer face-to-face.

Jeg har i det foregående belyst e-læringens muligheder med særligt henblik på glosetræning, tekstlæsning og skabelse af et fremmedsproget univers. Jeg har endvidere påpeget læringsjournalen som et uundværligt redskab for såvel den individuelle sprogindlærer som for samarbejdet imellem vejleder og sprogindlærer. I det følgende skal jeg se nærmere på sproglig e-læring i et netværksstøttet perspektiv.

\section{Netværksstøttet sproglig læring}

Ved termen netvcerksstøttet sproglig læring (NSSL) forstår jeg sproglig læring i det fysiske rum i kombination med sproglig læring støttet af kommunikation i lokale, nationale og internationale netværk. ${ }^{14}$ Denne såkaldte computermedierede kommunikation kan foregå imellem én-til-én, éntil-mange og mange-til-mange, og den antager typisk to former (Warschauer 1997):

- den asynkrone (med tidsintervaller) via mail, deltagelse i nyhedsgrupper, deltagelse i konferencer/debatfora i e-læringsplatforme,

- $\quad$ den synkrone (uden nævneværdige tidsintervaller), primært via chatfora. 
I min terminologi omfatter den computermedierede del af sproglig læring ikke alene egentlig kommunikation om og på fremmedsproget, men også forskellige øvelses- og opgavetyper, der direkte fokuserer på indarbejdelse af specifikke sproglige elementer. Med indtænkning af den iboende differentiering imellem det asynkrone og det synkrone medium, opstiller jeg nedenstående progression med seks niveauer:

1. asynkron NSSL (fokuseret træning af helt specifikke sproglige elementer (forståelsesorienterede og bundne produktive øvelser),

2. synkron NSSL (træning af afgrænsede sproglige elementer ( $\mathrm{fx}$ i form af informationskløft-opgaver, som løses online i små grupper sprogindlærerne imellem),

3. asynkron NSSL (kommunikation med et læringsmæssigt sigte sprogindlærere imellem (fx diskussioner og problemløsningsopgaver) med tidsforskydning,

4. synkron NSSL (kommunikation med et læringsmæssigt sigte sprogindlærere imellem (fx diskussioner og problemløsningsopgaver) uden nævneværdig tidsforskydning,

5. asynkron NSSL (kommunikation med tidsforskydning imellem sprogindlærere og indfødte sprogbrugere, enten med et egentligt læringsmæssigt sigte for deltagerne, som fx i e-tandem ${ }^{15}$, eller uden),

6. synkron NSSL (kommunikation uden nævneværdig tidsforskydning imellem sprogindlærere og indfødte sprogbrugere, enten med et egentligt læringsmæssigt sigte for deltagerne, som fx i e-tandem, eller uden).

Niveauerne spænder således fra fokuserede øvelsestyper, over friere kommunikation med et bredere læringsmæssigt sigte til ægte kommunikation med indfødte sprogbrugere. På trods af at sidstnævnte kan finde sted uden et specifikt sigte, kan sprogindlæreren i høj grad profitere heraf læringsmæssigt, specielt hvad angår udvikling af fluency på fremmedsproget.

Det teoretiske grundlag for ovenstående progression henter jeg fra kognitionspsykologien, der betragter sproglig læring som informationsbearbejdning. Det er en grundlæggende anskuelse at mennesket, og dermed også sprogindlærere, har en begrænset kognitiv bearbejdningskapacitet. Hvilken grad af kognitiv bearbejdning, en sproglig aktivitet udløser hos en sprogindlærer, er individuelt betinget og varierer fra sprogindlærer til sprogindlærer (McLaughlin/Rossman/McLeod 1983). Derfor vil det forholde sig således, at hvert niveau i progressionen vil fordre forskellige grader af kognitiv belastning hos den enkelte i henhold til det stadium i den intersproglige udviklingsproces, hvorpå man befinder sig (Ambjørn 2003). Differentieringspotentialet i progressionen skal primært findes i

- forholdet imellem forståelsesorienterede og produktive øvelser,

- forholdet imellem øvelser og egentlig kommunikation,

- forholdet imellem asynkron og synkron produktion hvad angår den kommunikative produktionshastighed,

- $\quad$ kompleksiteten i den sproglige produktion.

Der kan være mange gode grunde til at kombinere det fysiske og elektroniske læringsrum. I Ambjørn (2004b: 3) peger jeg på flg.:

- større uafhængighed i tid og rum,

- bedre kontaktmuligheder til underviser/vejleder og medstuderende,

- $\quad$ gget optag af omfattende og/eller komplekse informationer,

- $\quad$ øget tid til refleksion,

- løsninger af konkrete øvelser med efterfølgende respons og diskussion,

- videndeling. 
I det følgende vil jeg fokusere på yderligere tre faktorer, der alle relaterer direkte til differentiering og for mig hører til blandt de yderst essentielle, når det drejer sig om fordelene ved netværksstøttet sproglig læring.

\section{1 Øgede differentieringsmuligheder}

Generelt er differentieringsmulighederne i undervisningen i det fysiske rum, det være sig forelæsninger eller holdtimer, sparsomme. På en højere læreanstalt arbejder vi i sagens natur meget teoretisk. De fleste af teorierne er ganske nye for de studerende, og de kan være vanskelige at forstå. Forestillingen om et godt læringsmæssigt udbytte for et flertal i denne undervisningsform er illusorisk. De studerende møder op med forskellige forudsætninger, men undervisningen afvikles i henhold til den tidlige omtalte one size-model. Mundtlige fremlæggelser i det fysiske rum tillader ikke den enkelte at fravælge det overflødige eller fokusere ekstra på det komplekse, og den tillader ikke den enkelte at optage informationerne i eget tempo. Dertil kommer de større udsving i modtageres opmærksomhedskurve under længere fremlæggelser, hvilket betyder, at dele af stoffet ikke optages. De studerendes præferencer inden for læringsstile kan ikke tilgodeses med undervisning udelukkende i det fysiske rum, som ikke appellerer til dem, der er mere visuelt og taktilt orienterede. Endvidere er der i det fysiske rum mange forstyrrende elementer, der mindsker læringspotentialet, fx pladsmangel, uro og den blotte fysiske tilstedeværelse af andre personer, hvis udseende, påklædning og adfærd kan virke distraherende (Grevy 2004). Og sidst, men ikke mindst, kan et vist fravær fra lektioner i det fysiske rum ikke undgås.

Foruden præsentationer og fremlæggelser i det fysiske rum, bruges der i sprogundervisningen også meget tid på gennemgang af løsninger på øvelser og opgaver. Atter afspejles one sizemodellen med al tydelighed, idet det forudsættes, at alle studerende på et hold har mere eller mindre de samme behov. Sådanne aktiviteter er yderst tidskrævende og har en ringe læringsværdi for mange.

Ved at kombinere læring i det fysiske rum med læring i det elektroniske rum undgås de her skitserede problemstillinger, og differentieringen kan varetages i langt højere grad. Min erfaring er, at mundtlige gennemgange af et teoretisk stof derfor med stor fordel kan fastholdes, suppleres og nuanceres i form af støttematerialer i læringsplatformens fildeling samt instruerende og debatterende indlæg i de dertil indrettede fora. Og en gennemgang i et debatforum af løsningsforslag til diverse øvelser tillader de studerende at lægge hovedvægten på netop det, den enkelte har brug for og klikke sig hurtigt igennem stof, der er mindre relevant.

Hvad angår sidstnævnte, har jeg taget det skridt at erlægge gennemgang af øvelser til asynkron bearbejdning i det elektroniske rum (pkt. 1 i den opstillede progression). ${ }^{16}$ Konkret foregår det på den måde, at jeg hver semesteruge lægger et vist antal øvelser i hver sin tråd i et dertil indrettet forum i CampusNet. De fleste samarbejdsgrupper i faget har deres eget elektroniske samarbejdsrum, hvortil kun de selv har adgang, og hvor de i fællesskab udarbejder løsningsforslag til ugens øvelser. Efter at øvelsesformuleringerne fra min hånd er lagt i en tråd i et debatforum, modtager de studerende elektronisk en meddelelse om, hvilke udvalgte grupper der inden for en vis tidsfrist skal kopiere deres løsningsforslag fra deres grupperum over i en svartråd i fællesrummet. Herefter giver jeg direkte respons på dele af de indkomne forslag, medens jeg lægger andre ud til diskussion blandt alle deltagerne. Efterhånden som de studerende får erfaring i at bruge det elektroniske læringsrum, sker der oftere og oftere det, at nogle af dem selvstændigt tager initiativet til at give respons på hinandens løsningsforslag og diskutere dem frem og tilbage. 


\subsection{Computermedieret kommunikation}

De computermedierede interaktionsmuligheder udgør genremæssigt et hybridmedium mellem skrift- og talesprog, hvor specielt den uformelle synkrone chatform har mange lighedstræk med det talte sprog.

I kombinationen imellem sproglig læring i det fysiske og elektroniske rum ligger der en hensyntagen til kognitiv bearbejdningskapacitet, når det drejer sig om oparbejdelse af mundtlighed, herunder samtalefærdighed. I forskningen på området arbejdes der ud fra en tese om, at det skriftlige medium i det elektroniske rum har en faciliterende effekt på en efterfølgende mundtlig produktion face-to-face, hvilket logisk hænger sammen med mindre kognitiv belastning inden for det skriftlige medium med bedre tid til planlægning af produktionen (Warschauer/Kern 2000; Kern/Ware/Warschauer 2004). Beauvois (1998) benævner meget illustrerende computermedieret kommunikation conversation in slow motion.

På BA-studiets 4. semester, i faget 'Personlig kommunikation og IT', arbejder vi i spanskundervisningen på den opstillede progressions niveau 3 (jfr. afsnit 7), hvor computermedieret asynkron kommunikation på fremmedsproget indgår som et formidlende led imellem det skrevne og det talte $\operatorname{sprog}^{17}$. Med mig som mediator kommunikerer de studerende på spansk i mindre grupper i debatrum i CampusNet. Denne kommunikation har funktion af forberedelse til deltagelse i præsentationer, diskussioner og forhandlinger i de samme grupper face-to-face i det fysiske rum. Man kan på den måde sige, at den computermedierede kommunikation kommer til at virke som en conversation simulator (Payne/Whitney 2002).

\subsection{Fejlidentifikation og -korrektion}

Når man arbejder med fremmedsproglig mundtlighed, er man nødt til at forholde sig til problematikken omkring grammatisk fejlkorrektion. I den deltagercentrerede undervisningsform med fokus på kommunikativ effektivitet vil simultan grammatisk fejlkorrektion have en uheldig indvirkning på læringsprocessen. For det første vil de afbrydelser, denne korrektionsform afstedkommer i samtalen, virke forstyrrende på selve interaktionsforløbet, og dernæst vil den skabe et fokusskift fra indhold til form, hvilket på sin side vil spolere illusionen om "ægte kommunikation". I stedet for simultan fejlkorrektion anbefales det uforstyrret at lade de studerende producere talt sprog og anvende konsekutiv korrektion (Ambjørn 2001a).

Et andet argument for anvendelse af den konsekutive korrektionsform er hjernens begrænsede bearbejdningskapacitet, idet simultan fejlkorrektion ofte vil føre til mental overbelastning i den mundtlige produktionsproces. Det betyder, at simultan korrektion i de fleste tilfælde ingen nævneværdig effekt har.

På trods af den konsekutive korrektions utvivlsomt højere effektivitet inden for mundtlighed er det min erfaring, at heller ikke den fungerer optimalt. Til undervisningen på 4. semester, hvor vi, som beskrevet, arbejder med asynkron computermedieret kommunikation som forberedelse til arbejdet med mundtligheden i det fysiske rum, har jeg udviklet nedenstående model til differentieret fejlidentifikation og -korrektion i de debatindlæg, de studerende skriver på spansk:

\section{Forståelsesorienteret fejlidentifikation}

- $\quad$ i en sætning - identifikation af én fejltype

- $\quad$ i en sætning - identifikation af flere fejltyper

- $\quad$ i et tekstuddrag - identifikation af én fejltype

- $\quad$ i et tekstuddrag - identifikation af flere fejltyper

- $\quad$ i hele teksten - identifikation af én fejltype

- $\quad$ i hele teksten - identifikation af flere fejltyper 


\section{Produktiv fejlkorrektion}

- i en sætning - korrektion af én fejltype

- $\quad$ i en sætning - korrektion af flere fejltyper

- i et tekstuddrag - korrektion af én fejltype

- i et tekstuddrag - korrektion af flere fejltyper

- i hele teksten - korrektion af én fejltype

- $\quad$ i hele teksten - korrektion af flere fejltyper

Den forståelsesorienterede og den produktive fejlkorrektion kan anvendes hver for sig eller sammen. I sidste tilfælde kommer identifikation af fejlen logisk før korrektion af samme.

Endnu en differentieringsmulighed er ekspliciteringsgraden af fejltypen. Man kan vælge at anføre det område, den grammatiske fejl falder indenfor, eller man kan helt udelade remediale informationer.

Det er principielt afsender af et skriftligt debatindlæg, der identificerer og/eller korrigerer egne fejl. Men de andre gruppemedlemmer er velkomne til at bidrage med løsningsforslag til problemer, som afsender ikke selv kan klare.

\subsection{Forudsætninger}

Jeg har arbejdet med netværksstøttet sproglig læring siden 2002 og er fortsat inde i en forskningsbaseret udviklingsfase på området. Jeg kan ikke få øje på egentlige ulemper i forbindelse med denne form for læring, men en længere række af forudsætninger er nødvendige for, at den kan lykkes (Agertoft 2003a+b; Ambjørn 2004: 3):

- $\quad$ alle deltagere skal have sat sig grundigt ind i den pågældende læringsplatforms opbygning og kunne håndtere de grundlæggende funktioner,

- der skal fra undervisers/vejleders side udarbejdes retningslinjer for anvendelse af og adfærd i det elektroniske læringsrum,

- der fordres en høj grad af systematisk tænkning fra alle deltageres side, så overskueligheden i de elektroniske rum højnes,

- såvel underviser/vejleder som deltagere skal være indstillet på at indgå i et forpligtende samarbejde omkring læringen,

- såvel underviser/vejleder som deltagere skal via regelmæssig tilstedeværelse (såvel receptiv som produktiv) i de elektroniske debatfora påtage sig et medansvar for et optimalt udbytte af den netværksstøttede del af undervisningen,

- der fordres en høj grad af selvdisciplin fra såvel undervisers/vejleders som deltagers side,

- der fordres opmærksomhed fra såvel underviser/vejleder- som deltagerside rettet mod selve kommunikationen, dens form og vellykkethed.

Ovenstående forudsætninger er imidlertid ikke tilstrækkelige i sig selv. De studerende skal direkte og løbende bevidstgøres om både dem og om den praktiske adfærd i det elektroniske læringsrum, herunder om samarbejdets konkrete form, videndeling og netetikette. Endvidere skal de bevidstgøres om den netværksstøttede e-læringsforms store differentieringspotentiale og om de læringsteoretiske begrundelser for dens anvendelse.

Når der i undervisningen indgår computermedieret kommunikation på fremmedsproget, er det desuden hensigtsmæssigt at bevidstgøre om den autentiske sprogbrugs karakteristika i hhv. den synkrone og asynkrone kommunikation, i såvel uformelle som formelle fora. 


\subsection{Problemstillinger}

Hvad jeg endnu ikke har berørt, er de problemstillinger, der knytter sig til implementeringen af den netværksstøttede læringsform. Gennem en uformel undersøgelse på årgang 2003 har jeg fået indkredset årsagerne til, at det er forbundet med visse vanskeligheder at få læse- og skriveaktiviteten i en e-læringsplatform op på et acceptabelt niveau. Nedenstående begrundelser for den noget sporadiske tilstedeværelse i det elektroniske læringsrum er ikke anført i prioriteret, men tilfældig rækkefølge:

- usikkerhed over for it generelt,

- manglende internetforbindelse til hjemmecomputer,

- utilstrækkeligt kendskab til praktisk anvendelse af CampusNet,

- generel uoverskuelighed i CampusNet,

- manglende forståelse af formålet med læring i det elektroniske rum,

- manglende forståelse af fremgangsmåden ifm. håndtering af øvelser,

- skepsis over for netværksstøttet læring,

- manglende interesse for faget,

- manglende interesse for spanskstudiet.

Nogle af disse faktorer står det uden for den enkelte undervisers rækkevidde at øve indflydelse på. Men hvad angår specielt den manglende forståelse af formålet med læring i det elektroniske rum, af fremgangsmåden i forbindelse med øvelser samt generel skepsis over for undervisningsformen, er det muligt at sætte målrettet ind. Jeg intensiverede derfor fra og med årgang 2004 bevidstgørelsen om formål, potentiale og fremgangsmåde i den netværksstøttede læringsform. Resultatet af dette tiltag har været en markant højnelse af primært den receptive tilstedeværelse.

På både årgang 2004 og 2005 har den opfordrede produktion (løsningsforslag til diverse sproglige øvelser) kørt rimeligt uproblematisk med et aktivitetsniveau tæt på de $100 \%$ efter en vis indkørselsfase. Til gengæld skal der iværksættes aktiverende foranstaltninger, hvad angår den uopfordrede produktive tilstedeværelse, hvor deltagerne efter interesse og behov bidrager med enten initierende indlæg eller responderende og debatterende indlæg på andres indlæg. Med dette formål har jeg fra og med årgang 2005 indledt forskellige former for forsøg med selve kommunikationsformerne i det sproglige e-læringsrum for på sigt at få indkredset kriterierne for deres vellykkethed eller mangel på samme.

\section{Afrunding}

Med differentiering som den røde tråd, har jeg med relation til egen undervisningspraksis ønsket at belyse forskellige forudsætninger for et optimalt udbytte af udvalgte aspekter af den sproglige e-lærings potentiale. Endvidere har jeg, som et led i e-læringskonceptet, plæderet for integration af netværksstøttet sproglig læring og skildret dens fordele, forudsætninger og problemstillinger. Endelig har jeg kort berørt egne igangværende tiltag, der forhåbentligt kan bidrage til en optimering af den netværksstøttede sproglige lærings potentiale.

\section{Litteratur}

Agertoft, Annelise m.fl. (2003a): Netbaseret kollaborativ lering. En guide til undervisere. Værløse: Billesø og Baltzer.

Agertoft, Annelise m.fl. (2003b): Deltager i netbaseret laring. En guide til samarbejde. Værløse: Billesø og Baltzer.

Ambjørn, Lone (1999): Samtalefærdighed og medansvar. Sprogforum, 14/5, 56-60. http://inet.dpb.dpu.dk/infodok/sprogforum/spr14/ambjoern.html

Ambjørn, Lone (2001a): Talt interaktion anskuet i et diskursivt, pragmatisk og strategisk perspektiv. Webpublikation, Research@asb, http://130.226.203.32/fbspretrieve/38/0003049.pdf

Ambjørn, Lone (2001b): Proces, medansvar og differentiering i oparbejdelse af den leksikalske kompetence. Webpublikation, Research@asb, http://130.226.203.32/fbspretrieve/34/0003041.pdf 
Ambjørn, Lone (2002a): Sproglige læringsprocesser og IT. - Sproglæringsteoretisk værktøj til udvikling af ITstøttede materialer og programmer til sprogundervisningen. Working Paper, Webpublikation, Research@asb. http://130.226.203.32/fbspretrieve/37/0003197.pdf

Ambjørn, Lone (2002b): Formalsproglig kompetence og IT. - Sproglæringsteoretisk værktøj til udvikling af IT-støttede materialer og programmer inden for grammatikalsk og leksikalsk kompetence. Working Paper, Webpublikation, Research@asb. http://130.226.203.32/fbspretrieve/27/0003201.pdf

Ambjørn, Lone (2002c): Receptive processer og IT. - Sproglæringsteoretisk værktøj til udvikling af ITstøttede materialer og programmer inden for sproglig reception. Working Paper, Webpublikation, Research@asb. http://130.226.203.32/fbspretrieve/36/0003198.pdf

Ambjørn, Lone (2003): Computermediets differentieringspotentiale i sproglig læring belyst ud fra en procesorienteret synsvinkel. Hermes, 30, 13-37. http://130.226.203.32/fbspretrieve/24/0003107.pdf

Ambjørn, Lone (2004a): Produktive processer og IT. - Sproglæringsteoretisk værktøj til udvikling af ITstøttede materialer og programmer inden for sproglig produktion. Working Paper, Webpublikation, Research@asb. http://130.226.203.32/fbspretrieve/35/0003202.pdf

Ambjørn, Lone (2004b): Netværksbaseret sproglig læring i CampusNet. Webpublikation, LearningNet.dk. http://130.226.203.32/fbspretrieve/32/Netv_rksbaseret_sproglig_l_ring_i_CampusNet.pdf

Beauvois, Margaret H. (1998): Conversations in slow motion: Computer-mediated communiacation in the foreign language classroom. The Canadian Language Review, 54/2, 198-217.

Coady, James (1997): L2 vocabulary acquisition through extensive reading.

I T. Huckin /J. Coady, 225-237.

Ebbinghaus, H. (1885): Über das Gedächtnis. Leipzig: Von Duncker and Humblot.

Grabe, William (2004): Research on teaching reading. Annual Review of Applied Linguistics, 24, 44-69.

Grevy, Carlo (2004): Klasseværelset, kroppen og teknologien - fra landsbyskole til interaktionssamfund. Emergens, 3, 2-15. http://www.cvusonderjylland.dk/index.php?cccpage=cvu_udgivelser_emerg3a2

Haastrup, Kirsten (1989): Fremmedsproglig reception: Lytte og læseforståelse. I Kasper/Wagner (red.): Grundbog i fremmedsprogspcedagogik, 20-35.

Hirsh, David /Nation, Paul (1992): What vocabulary size is needed to read unsimplified texts for pleasure? Reading in a Foreign Language, 8/2, 689-696.

Huckin, Thomas/Coady, James (1999): Incidental vocabulary acquisition in a second language. SSLA, 21, 181-193.

Kern, Richard/Ware, Page/Warschauer, Mark (2004): Crossing frontiers: New directions in online pedagogy and research. Annual Review of Applied Linguistics, 24, 243-260.

Landauer, T.K./Bjork, R.A. (1978): Optimum rehearsal patterns and name learning. I Gruneberg/Morris/Sykes (red.), Practical aspects of memory, 625-632.

Leitner, S. (1972): So lernt man lernen. Freiburg: Herder.

McLaughlin, Barry/Rossman, Tammi/McLeod, Beverly (1983): Second language learning: An information-processing perspective. Language Learning, 33/2.

Mondria, Jan-Arjen/Mondria-De Vries, Siebrich (1994): Efficiently memorizing words with the help of word cards and "hand computer": Theory and applications. System, 22/1, 47-57.

Moskovsjy, Christo (2001): The Critical Period Hypothesis Revisited. Webpublikation, Proceedings of the 2001 Conference of the Australian Linguistic Society.

http://linguistics.anu.edu.au/ALS2001/papers/Moskovsky.pdf

Nation, Paul (1990): Teaching and learning vocabulary. New York: Newbury House Publishers.

Nation, Paul/Newton, Jonathan (1997): Teaching vocabulary training.

I T. Huckin/J. Cody: 238-254.

Nation, Paul/Waring, Robert (1997): Vocabulary size, text coverage and word lists. I Schmitt/McCarthy: 6-19.

Nunan, David (1999): Second Language Teaching \& Learning. Boston, Massachusetts, Heinle \& Heinle Publishers.

Schmitt, Norbert/McCarthy (red.) (1997): Vocabulary. Description, acquisition and pedagogy. Cambridge University Press.

Seeley, Ned/Day, Laurence (1971): Penetrating the mass media: A unit to develop skill in reading Spanish newspaper headlines. Foreign Language Annals, 5/1, 69-81.

Selinker, Larry (1972): Interlanguage. International Review of Applied Linguistics 10, 209-230. 
Simensen, Aud Marit (1998): Teaching a foreign language. - Principles and procedures.

Bergen - Sandviken: Fagbokforlaget.

Tomlinson, Carol Ann (2000): How to differentiate instruction. Reconcilable differences?

Educational Leadership, 58/1, 1-7.

Tornberg, Ulrika (2001): Sprogdidaktik.

København: L\&R Uddannelse A/S.

Warschauer, Mark (1997): Computer-Mediated Collaborative Learning: Theory and Practice.

Modern Language Journal, 81/4, 470-81.

Warschauer, Mark/Kern, Richard (2000): Network-based language teaching: Concepts and practice. Cambridge University Press.

${ }^{1}$ Inden for disciplinerne Spansk kommunikation (1. - 3. sem.) og Personlig kommunikation og IT (4. sem.) på BAstudiet, hvor der på forskellig vis fokuseres på oparbejdelse af mundtligheden.

${ }^{2}$ Intersproget er det sprog, der hverken er modersmålet eller fremmedsproget, og som sprogindlæreren gradvist udvikler i retning af fremmedsproget. (Se evt. mere om intersproget i Ambjørn 2003: 3-5).

${ }^{3}$ Se evt. nærmere om disse emner i Ambjørn 2003.

${ }^{4}$ I hovedtræk går hypotesen på, at barnets evne til at tilegne sig sprog som en ubevidst proces, ikke findes i så udtalt grad hos voksne. Naturlig tilegnelse af sprog kan bedst finde sted i alderen fra 2 år til puberteten. Efter puberteten vanskeliggøres tilegnelsesprocessen pga. af tab af cerebral plasticitet. Det nægtes ikke, at man som voksen kan indlære sprog som en bevidst proces, men automatisk sprogtilegnelse ved konfrontation med et fremmedsprog synes at reduceres med puberteten. Se evt. nærmere herom i Moskovsky (2001).

${ }^{5}$ En ordfamilie består af et basisord + bøjede og afledte former (fx find, finds, found, finder, findings).

${ }^{6}$ http://gbcdesign.dk/

${ }^{7}$ Til den spanske version findes dog et glosesæt på 2500 basale gloser, som jeg har udarbejdet til mine studerende. Denne remediale foranstaltning er begrundet $i$, at mange ved studiestart har et mangelfuldt ordforråd, og at de så hurtigt som muligt skal bibringes det fornødne leksikalske fundament til læsning af autentiske tekster og til udviklingen af deres mundtlighed. Det basale glosesæt skal den enkelte bruger løbende supplere med egne gloser, hvilket principielt kan foregå hele studietiden igennem samt efterfølgende.

${ }^{8}$ For en ordens skyld skal jeg nævne, at de studerende, sideløbende med min disciplin, på 1. - 3. sem. tilbydes undervisning i grammatik, kultur \& samfund samt skriftlig erhvervskommunikation.

${ }^{9}$ http://www.sprog.asb.dk/lam/startside/Default.htm

${ }^{10}$ Da faget tager sigte på samtalefærdighed, læses også talesprogstekster. Disse foreligger i traditionel trykt form og suppleres med video og lydbånd.

11 Det viser sig i praksis, at langt de fleste studerende fejlagtigt sidestiller resumeteknikken med oversættelse.

12 Det er fortsat en ret udbredt misforståelse, at sprogindlærernes forståelse skal tjekkes via sproglig produktion.

En sprogindlærer kan som regel forstå mere, end h/n er i stand til at udtrykke på fremmedsproget.

13 Jeg anvender termen leringsjournal synonymt med logbog.

14 Svarer omtrentligt til termen blended learning.

15 Se http://www.slf.ruhr-uni-bochum.de/etandem/etproj-da.html

${ }^{16}$ Det drejer sig på 1. - 3. sem. om øvelser rettet mod såvel forståelsesorienteret analyse som bunden produktion af diverse elementer inden for talesprogsdiskurs og dialogopbygning. Endvidere indgår de tidligere omtalte resumeer af avisoverskrifter plus manchetter.

${ }^{17}$ Progressionens niveau 5 og 6 varetages selvstændigt af den enkelte studerende efter behov og interesse og som led i skabelsen af 'det spanske univers' (jf. afsnit 5). 